How to cite: Moroşanu, G.A., Zaharia, L., Belleudy, Ph. (2019) Applying Colorimetric and Image Analysis Methods to Identify the Coal Areas Contributing to the Hydro-Sedimentary Dynamics in Jiu River Basin. 2019 "Air and Water - Components of the Environment"Conference Proceedings, Cluj-Napoca, Romania, p. 19-30, DOI: 10.24193/AWC2019_03.

\title{
APPLYING COLORIMETRIC AND IMAGE ANALYSIS METHODS TO IDENTIFY THE COAL AREAS CONTRIBUTING TO THE HYDRO-SEDIMENTARY DYNAMICS IN JIU RIVER BASIN
}

\author{
Gabriela Adina MOROŞANU ${ }^{1,2,3}$ 凹, Liliana ZAHARIA ${ }^{1}$, Philippe BELLEUDY ${ }^{3}$
}

DOI: 10.24193/AWC2019_03

\begin{abstract}
Jiu River, one of the most important Danube tributaries in South-Western Romania, is about $340 \mathrm{~km}$ long, with a catchment area of $10,080 \mathrm{~km}^{2}$. The Jiu River basin is distinguished by the presence of coal mining areas (bituminous coal in the upper sector - the Petroşani depression, and lignite in the middle sector - the Motru-Rovinari basin), which impacts the composition of fine sediments through the incorporation of coal particles. The general goal of the paper is to determine the presence of coal and estimate the proportion of coaly particles in the fine sediments transferred within the Jiu watershed, by using visual-based methods, namely colorimetric and image analysis applied on 88 samples of fine river sediment collected from Jiu River and its main tributaries and on 5 samples of bulk coal taken from mining areas. The colour-based approach conducted to a better characterisation of the river sediments and coal samples in terms of the colour shades that could highlight the presence of coal. The best explanatory index proved to be $\mathrm{a}^{*}$, closely followed by $\mathrm{b}^{*}, \mathrm{y}, \mathrm{C}^{*}$ and $\mathrm{v}^{\prime}$, which were further used in the automatic interaction detection models. There was no evident link between coal content seen from the coal grains surface (\%) point of view through image analysis and the distribution of colorimetric indices for Jiu river and its tributaries.

Still, the automatic interaction detection analysis succeeded to correctly classify the lignite and for a part of the bituminous coal samples (the fractions <20 $\mu \mathrm{m}$ ). The remaining coarser fractions of bituminous coal samples were confused with lignite particles and could not be used as predictors for sediment samples with coal content.
\end{abstract}

Keywords: coal particles, colorimetry, fine sediments, image analysis, Jiu River Basin

\section{INTRODUCTION}

Research on the origin and composition of fine-grained sediments transported by rivers is an important step in the analysis of the hydro-sedimentary balance, useful for a complete diagnosis of the sediment dynamics in a river basin, in order to adopt proper management practices, taking into account not only the variability of liquid discharge

1 University of Bucharest, Faculty of Geography, Bd. Nicolae Bălcescu 1, Bucharest, 010041, Romania gabriela.adina.m@gmail.com zaharialili@hotmail.com

${ }^{2}$ The Geography Institute of the Romanian Academy, Street Dimitrie Racoviță 12, Bucharest, 023991, Romania

${ }^{3}$ University of Grenoble Alpes, Institut des Géosciences de l'Environnement, UGA - IGE, CS 40700, 38058, Grenoble Cedex 9, France philippe.belleudy@univ-grenoble-alpes.fr 
but also the sediment fluxes (Navratil et al., 2012; ISRBC, 2015; Latuf \& Amaral, 2016). The importance of fine sediment quality and quantity in water resources conservation within river basins has been widely recognized, especially when it comes to monitoring sediment nutrient concentrations (Owens et al., 2005; SedNet, 2009). Following numerous studies on processes at different spatial scales (from the granular level to the scale of the entire valley slope) contributing to suspended sediment delivery, a number of fine sediment sources have been highlighted: mechanical and/or chemical weathering, erosion and transport of weathered material, resuspension, fragmental sediment release from human activities on the soil and geological aggregates, etc (Navratil et al., 2012; Juez et al., 2018). Although dissolved sediments and bedload are two of the three main components of the solid matter transported in rivers, along with suspended sediment, most hydro-sedimentary dynamics studies have paid particular attention to the issue of determining the proportion of the latter, due to its role in the morphological, hydrological and ecological functioning of a river (Owens et al., 2005; Piqué Altés, 2017).

In order to estimate the sediment yield, it is essential to determine the type of sediment sources (Sang et al., 2018). The identification of the sediment sources in a river system has been possible through the implementation of a whole panoply of techniques such as: geochemistry, radionuclides and sediment core analysis, sediment fingerprinting, remote sensing, etc (Navratil et al., 2012; Haddachi et al., 2013; Legout et al., 2013; Némery et al., 2013; Sang et al., 2018). Sediment delivery is strongly variable in time, but it primarily differs in terms of geochemical composition, due to the lithology and the human activities impacts on their formation (Piqué Altés, 2017).

The present research aims to investigate the contribution of areas with coal mining activities to the fine sediment delivery in watercourses, by adapting medicine and biology-derived methods in geosciences, namely colorimetric and image analysis. The methodological approach relies on the slight colour difference between bituminous coal and lignite, which makes coal particles an easy-to-use tracer.

\section{STUDY AREA}

The study area corresponds to Jiu River Basin $\left(10,080 \mathrm{~km}^{2}\right)$, located in SW Romania (Fig. 1), with a variety of landforms, diverse lithology, soils and land cover, as well as with various economic activities. Representative, and at the same time problematic for this study area in terms of fine sediment delivery, is coal mining still based on outdated technical standards. The poor management of coal tailings and coal washing leads to water and sediment pollution. In this way, a nonnegligible amount of coal particles reaches the river through erosion and transport on the slopes and in the riverbeds, and also through the direct release of coal during mining activities, subsequently mixing with the native sediments.

In the Jiu River basin, two coal mining areas are reported (Fig. 1), each one corresponding to a different coal species (Standard Classification of Coals - ASTM International D388): bituminous coal in the upper basin along the Petroșani 
Depression and lignite, in the middle sector of the catchment, in the Motru Rovinari coal basin (Preda, 1979; Rădoane \& Rădoane, 2005).

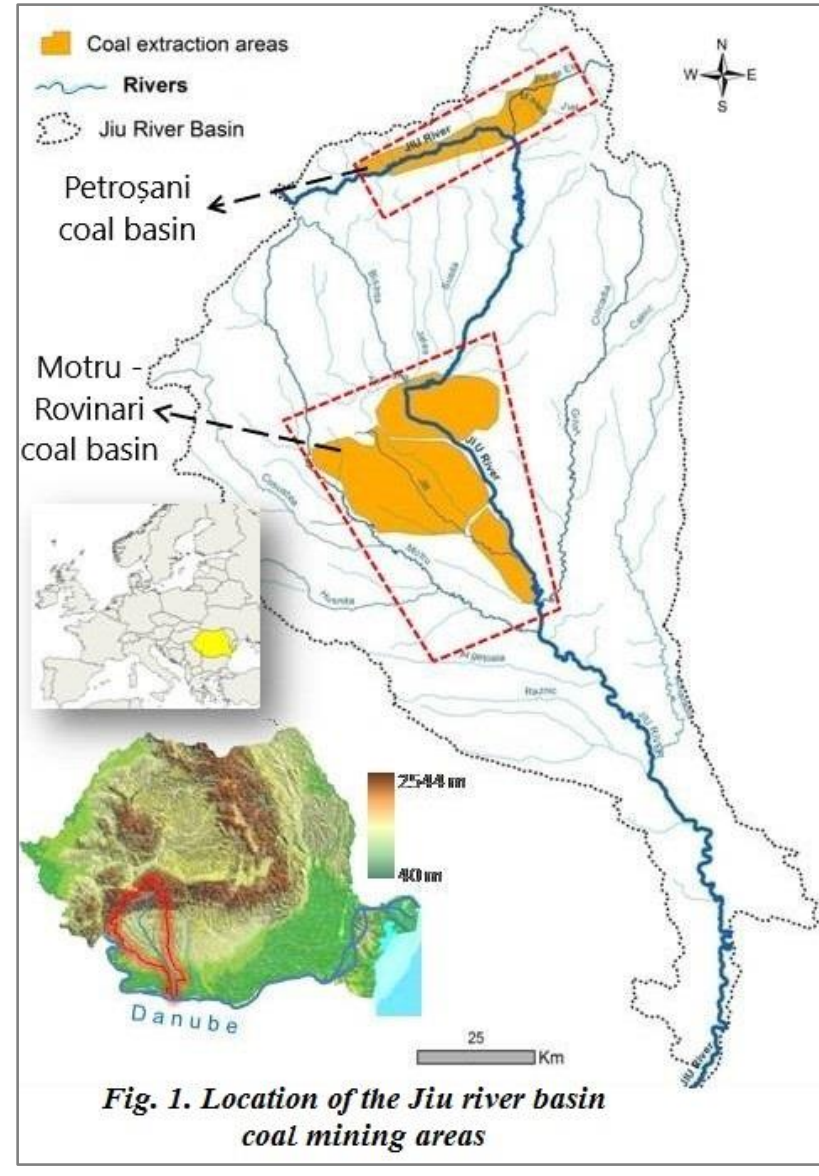

In this specific geographic and economic context, coal-enriched sediments are regarded as a crucial indicator in understanding this origin and mineral composition of the fluvial sediments. This is evident since, in the fine sediments of the river beds and banks, one can noticeably find, in different proportions, besides the dominant mineral fraction, coal particles originating from the industrial activities. Consequently, the working hypothesis of our study assumes that native sediment composition is strongly influenced by the interference of coal particles coming from the two main coal extraction areas within Jiu River Basin.

\section{DATA AND METHODS}

\subsection{Sediment sampling strategy}

In order to identify the origin of fine sediments, following field campaigns in the summer of 2016 and 2017 (during medium-water hydrological regime), 88 fine sediment samples were taken from the Jiu River basin. The choice of the sampling points respected the general logic of the erosion - transport - deposition processes, for the representativity of the source and storage areas. The hypothesis on which the sampling campaign was based was that fine alluvia deposited in riverbeds originated from the transfer of sediment in suspension and reflected the contribution of upstream sediment sources. Regarding the source areas, consideration was given not only to the presence of sediments from the mining basins, but also to other subcatchments that do not necessarily overlap the coal exploitation areas. The 
downstream sectors of the main rivers were considered to be the deposition areas, i.e. the tributaries of the Jiu River and the Jiu River itself, in its middle-lower sector, between Filiaşi and the Danube. Fig. 2 shows the relative location of the fine sediment sampling points within the Jiu river basin, along with some pictures that illustrate the sampling strategy, either from the pavement of the armor layer of the riverbeds or from the alluvial vertical layers exposed by digging a riverbank profile of Jiu river downstream the Podari hydrometric station.

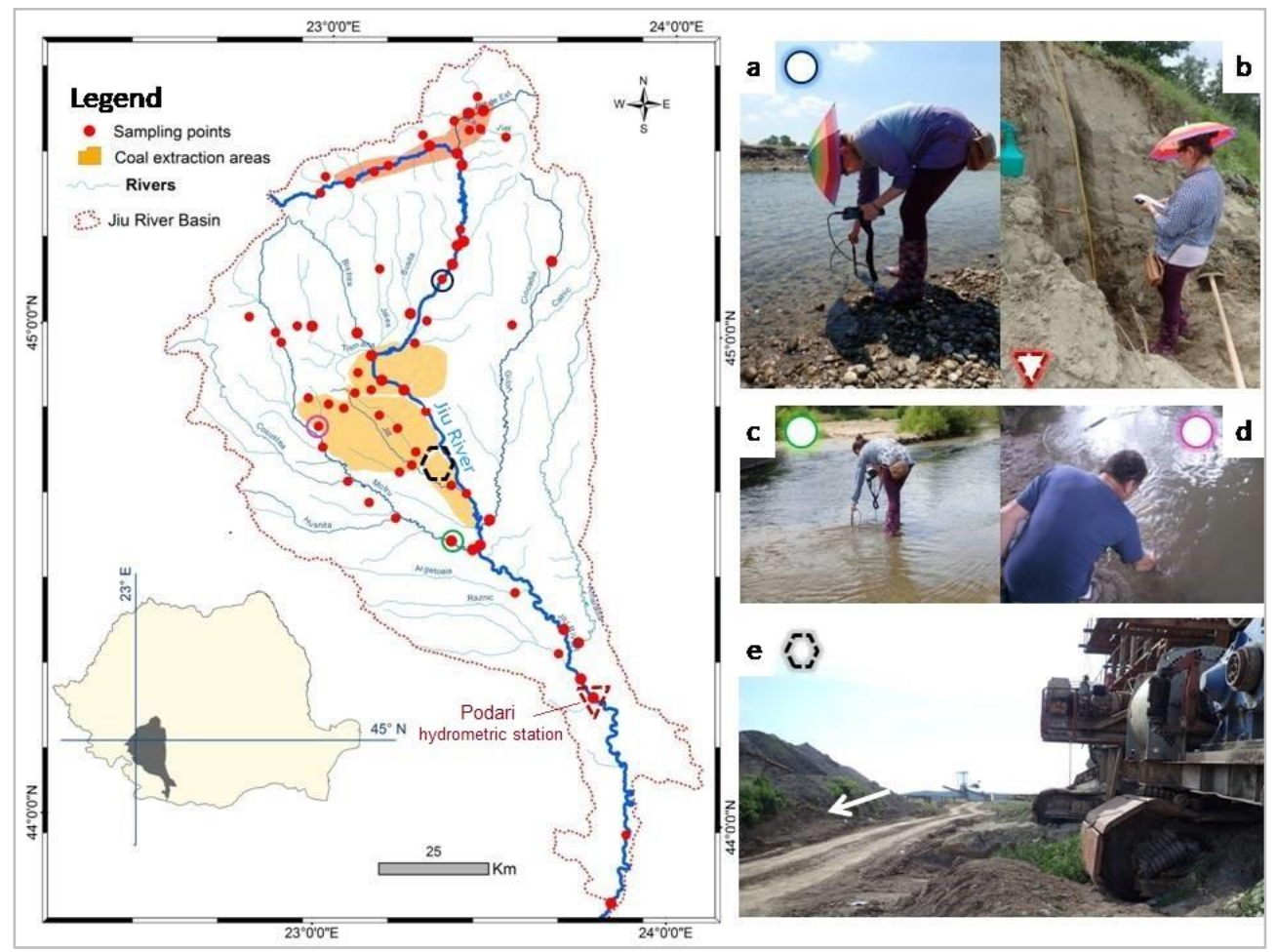

Fig. 2. Fine sediments sampling points within the Jiu River Basin. Photos: a, c, driverbed sampling; $b$ - riverbank vertical profile (sediment deposits); $e$-coal tailings

Out of the 88 samples of fine sediments, 77 were gathered from the riverbeds' pavement underneath the first layer directly in contact with water (46 samples from the main tributaries, and 31 samples from the Jiu River - Fig. 2.a, c, d). As for the remaining 11 ones, they are representative for the alluvial layers succesively deposited on top of each other to build an accumulation riverbank downstream the main (and nearly all) possible sediment sources of Jiu River (Fig 2.b). The delimitation of the 11 layers most likely deposited by the largest floods in recent decades has been made according to the differences in texture and color that could be observed on the spot at the moment when the profile trench was dug. Additionnaly, another 5 samples of bulk coal were taken from mining areas, generally from tailings dumps distributed evenly within the bituminous coal and lignite basins (Fig. 2.e). 


\subsection{Preparation of the samples}

In preparing the sediment and bulk coal samples, several procedures were followed (Fig. 3): (i) river sediments' preparation according to color and counting measurements: drying in an oven at $105^{\circ} \mathrm{C}$, manual crushing using a porcelain mortar, sieving at $63 \mu \mathrm{m}$ using metal sieves, ultrasonic cleaning to get rid of the organic particles; (ii) bulk coal samples preparation required that the large particles be crushed in a laboratory blender, before submitting them to manual sieving to different granulometric fractions $(<63 \mu \mathrm{m}, 40 \mu \mathrm{m}$ and $20 \mu \mathrm{m})$, subsequently moving on to determining the specific spectrocolorimetric signatures of the two coal species. Following these preparatory steps, sediment and coal samples were stored in $40 \mathrm{ml}$ transparent plastic containers and their lids were numbered.
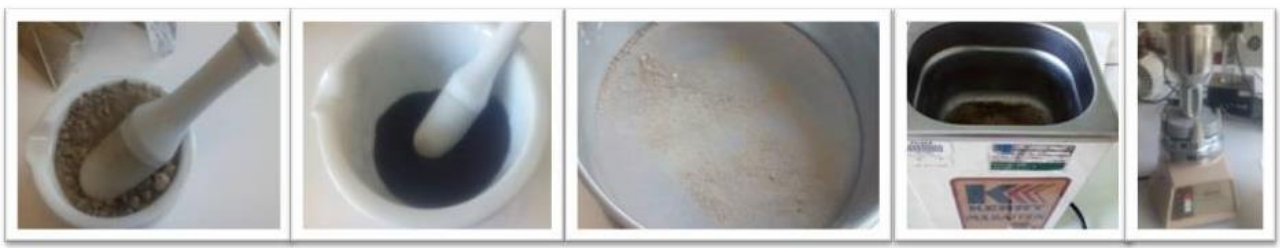

Fig. 3. The samples' preparation steps. From left to right: manual crushing of sediments and bulk coal, sieving, ultrasonic cleaning of river sediments, and coal smoothing from coarse to fine grains in a laboratory blender

\subsection{Methods}

\subsubsection{Image analysis}

The image analyses were performed using a binocular magnifying glass Leica LAZ on sediments sieved to particle size $<63 \mu \mathrm{m}$ fraction. Since the purpose of this analysis was to determine the proportion of coal grains relative to the inorganic mass of sediment samples, at this stage, we processed only the sediment samples, and not the coal ones.

The protocol for capturing images required the pre-preparation of a white $3 \times 3$ $\mathrm{cm}$ background paper sheet on which sediment particles from each sample were uniformly scattered. Images on the binocular magnifier were taken in direct and indirect light, following the photometric characteristics presented in Table 1.

Table 1. The settings of the image analysis at the binocular magnifying glass

\begin{tabular}{|c|c|c|c|}
\hline \multicolumn{2}{|c|}{ Image Calibration } & \multicolumn{2}{c|}{ Dimensions } \\
\hline On graph paper as background & Calibrated image size & Zoom & Resolution \\
\hline 1 pixel = 0.0013 mm & $2.58 \times 1.93 \mathrm{~mm}$ & $5 \mathrm{x}$ & 24 bits/ pixel \\
\hline Image type & Brightness & Gamma & Saturation \\
\hline Color and Black \& White & $32 \%$ & 0.7 & 135 \\
\hline
\end{tabular}

Three such images with the above-mentioned characteristics of each sample were used to achieve an average estimate of the percentage of coal particles. The classification was made using the Traceable Weka Segmentation algorithm in the ImageJ Image Processing Software (Prodanov \& Verstreken, 2012; Arganda-Carreras 
et al., 2017). For each image, 3 classes were considered: coal grains, other (mineral) particles, background (Fig. 4). The average percentage for each class, particularly the coal grain, was determined using an image color summarizer plugin in R Studio.

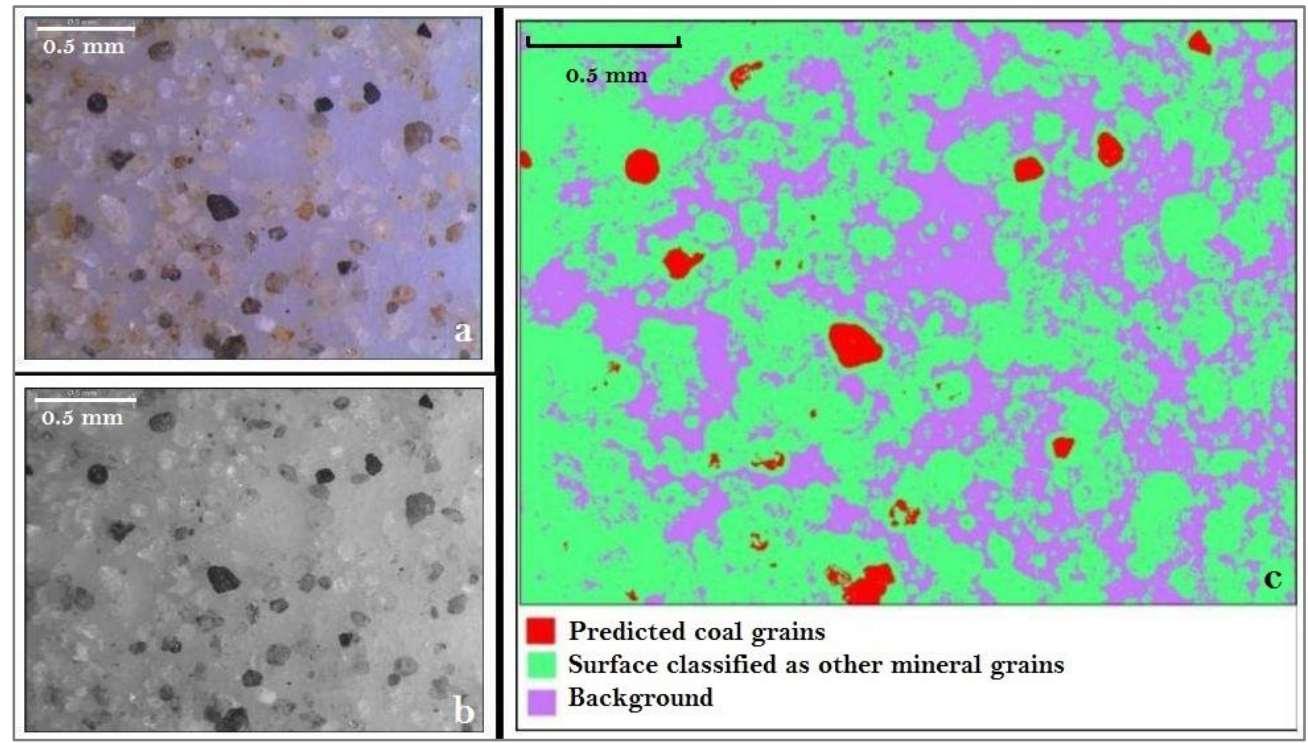

Fig. 4. An example of the result of the supervised classification: $a$-color version; $b-$ black \& white version; $c$-classified image

Following the images classification, the approximate visual ratio of the coal particles in each sediment sample was obtained. Finally, to analyze the relationship between sediment color and "coal content" according to image analysis, factorial analysis (PCA), linear regression, and simple correlations were used.

\subsubsection{Colorimetry}

In order to discriminate between the contributing sub-catchments, as well as between source areas of the sedimentary material reaching the main river, spectroscopic measurements were carried out on the dried sediment and bulk coal samples. A portable diffuse reflectance spectrophotometer (Konica Minolta 2600d) was used to predict, through visible reflectance spectroscopy (VIS), the proportion of source materials (the two-coal species within the mineral fraction of various origins of the fine sediments) in recent riverbed and riverbank deposits.

Basically, the technique explores the three dimensions (hue, lightness, saturation) of a solid. Over time, various colour coding systems have come out (Konica Minolta, 2009), among which we mention the following: Munsell Renotation System (HVC) Fig. 5.a; XYZ tristimulus values; L·a b color space. Spectral measurements were made in the 360-740 nm interval on sediment particles smaller than $63 \mu \mathrm{m}$ after sieving. The spectrocolorimeter was installed bottom-up, and transparent plastic tubes containing the samples were placed on its measuring cell (Fig. 5.b), so that the 3-mm radius circle beam sent over it would integrate a compact layer of roughly $100 \mathrm{mg}$ per 
sample (Legout et al., 2013). To account for the heterogeneity of the colorimetric properties of the samples, and to avoid possible measurement errors and unspecific signals, we took three measurements for each sample (Legout et al., 2013).

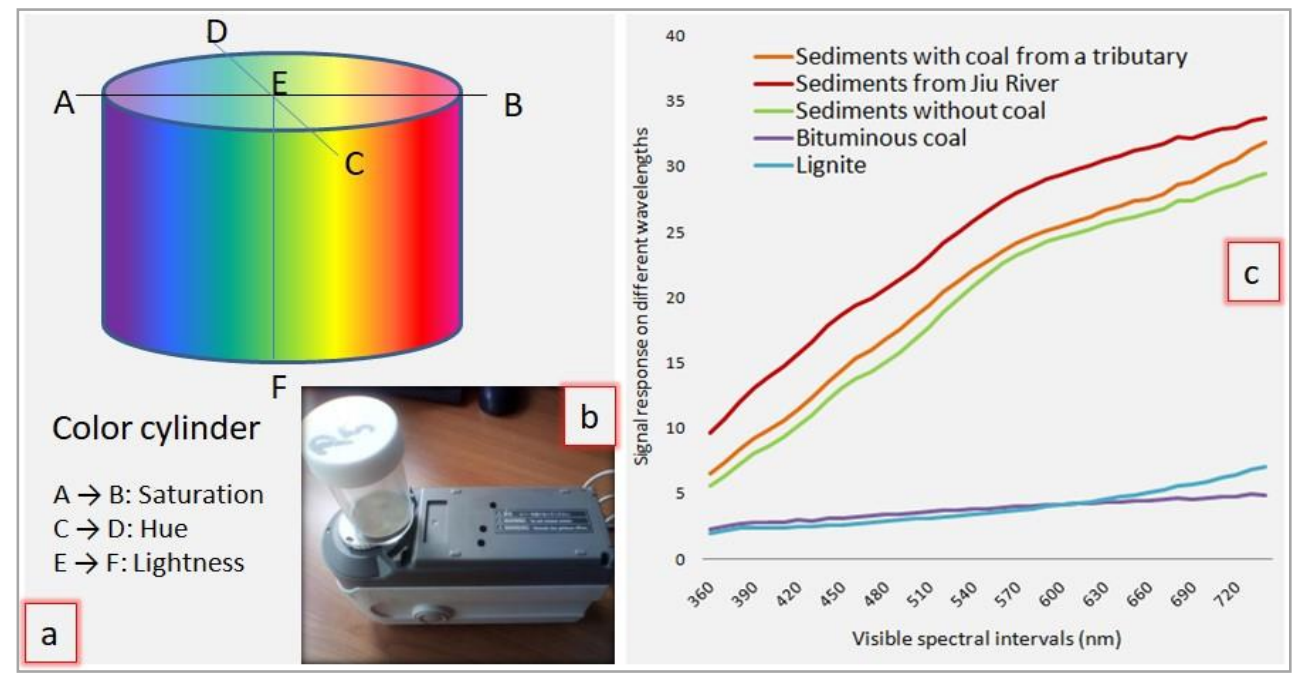

Fig. 5. The representation of the spectrocolorimetric concept: $a$. - the scheme of a colour space solid; $b$. - the measurements under the spectrocolorimeter; $c$. Distribution of the visible spectrum for different sample categories

Spectral reflectance was measured between 360 and $740 \mathrm{~nm}$ with a $10-\mathrm{nm}$ resolution (Viscara Rossel et al., 2006). Depending on how intense the color of sediment is and how close to black or white is, the spectrocolorimetric response is different. For indication, Fig. 5.c demonstrates how the more clean the sample is, the higher the spectrocolorimetric signal attained. Likewise, higher the coal quantity in the sediment sample leads to a lower ratio between the reflected light coming back from the sample and a white standard, as the sample subjected to the measurement will behave like a black body absorbing the standard Xenon arc light emitted by the spectrophotometer. Next, colorimetric indices were calculated based on the spectral reflectance percentage for each of the 39-wavelength classes and were integrated into statistical models to identify the spatial distribution of the spectrocolorimetric signal indicating the presence of coal in sediments.

After processing the spectrocolorimetric signal, statistical classification models, factorial analysis and correlations were conducted in order to investigate whether coal particles found in the sediment and coal samples within the Jiu River Basin could be used as predictors for the proportion of coal in sediment samples from the Jiu riverbank further downstream. Whereas the riverbed alluvial material samples in Jiu River and its tributaries may have resulted from suspension and deposition processes (considered or intermediate sources or storage areas), the alluvial layers from Jiu riverbank at Podari were certainly built by most active floods in terms of fine sediment transfer. In the quest for the relationship between upstream sources of coal enriched river sediments and downstream accumulations, Chi-square automatic 
interaction detection (CHAID) method was subsequently employed to investigate the prediction rate of a sample belonging to one group or another. For this aim, classifications were made splitting the coal and sediment samples in different classes.

\section{RESULTS AND DISCUSSIONS}

Based on the spectral graph of each sediment and coal sample, different colorimetric indices were calculated using the formulas specific to the different colour systems mentioned in \$3.3.2 (Konica Minolta, 2009). The resulting colorimetric indices were integrated in statistical classification models as potential predictors of the proportion of coal in the source sediment samples from the riverbeds and those from the riverbank alluvial deposit (Legout et al., 2013).

According to the 15 colorimetric indices $\left(\mathrm{L}^{*}, \mathrm{a}^{*}, \mathrm{~b}^{*}, \mathrm{C}^{*}, \mathrm{~h}, \mathrm{x}, \mathrm{y}, \mathrm{z}, \mathrm{a}, \mathrm{b}, \mathrm{u}^{*}, \mathrm{v}^{*}\right.$, $\left.\mathrm{u}^{*}\right)$, the best correlations between the coal-specific chromes and the amount of coal particles from the image analysis were obtained for the $\alpha^{*}, y$ and $v^{\prime}$ (Fig. 6).

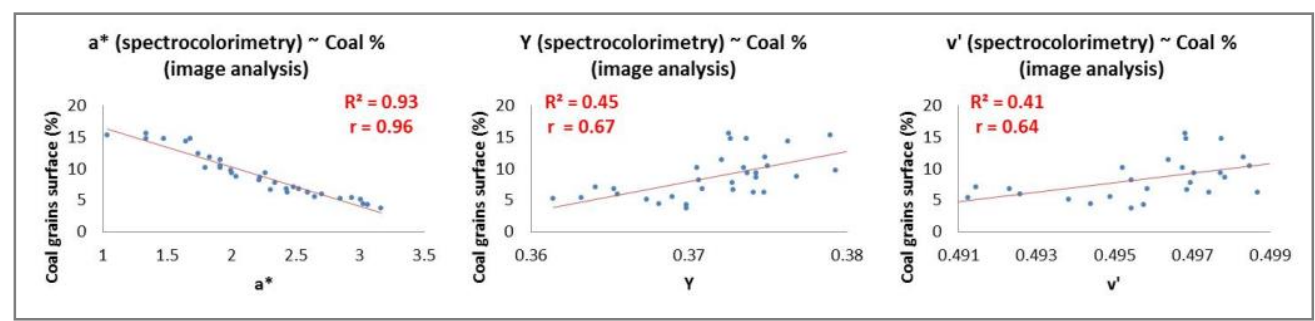

Fig. 6. Best correlations between C\% (images analysis) and different colorimetric indices of the fine sediment samples collected from Jiu River and its main tributaries

Correlations were also performed for the 11 values of the coal grains percentage in the downstream sediment samples from Podari alluvial layers, but due to the dependence on the number of paired data, the correlation coefficients were low for all the colour indices. The strongest correlation between the colorimetric indices and the percentage of the area occupied by coal grains in the total area of sediment grains (other minerals included) was found in the case of $\mathrm{C}^{*}$ and $\mathrm{b}^{*}$ indices $(\mathrm{r}=0.37$ and $\mathrm{r}=0.35$ respectively). However, one should bear in mind that the correlations were performed at the cost of statistical power, because of the insufficient number of values.

Regarding bulk coal samples from source areas, no image classification was made, as it would have been difficult to distinguish bituminous coal particles from lignite ones. Instead, the visible spectrum and colorimetric indices were calculated for these samples. Since the differences between lignite and bituminous coal increasingly fade to granulometric fractions larger than $63 \mu \mathrm{m}$ (ranging from grain-size classes to $1 \mathrm{~mm}$ particle size measurements), the results obtained for the fractions of 40 and 20 microns were considered more eloquent. Hence, it is an obvious difference between the spectral response of the different coal samples for fractions $<40 \mu \mathrm{m},<20 \mu \mathrm{m}$ for lignite vs. bituminous coal samples than one should have found for fractions $<63 \mu \mathrm{m}$. Surprisingly, although the correlations between the "coal content" estimated by image 
analysis and the various colorimetric indices were not necessarily representative in terms of the relationship between the colorimetric spectrum of the source coal samples and those of downstream sediments accumulated on the Jiu riverbank at Podari, since only very high values of the correlation coefficients were obtained (Fig. 7).

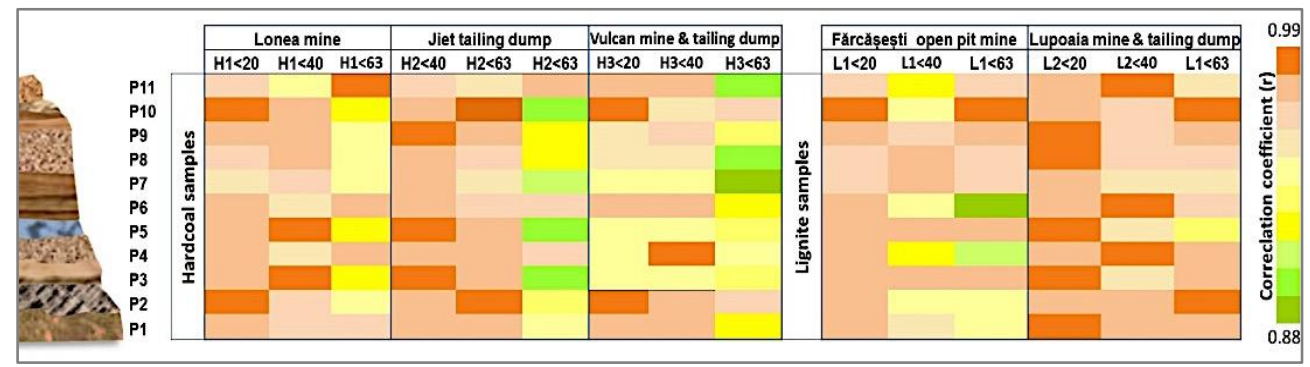

Fig. 7. The magnitude of the correlation coefficient between the different colorimetric indices obtained for coal source samples $(\mathrm{H1}, \mathrm{H2}, \mathrm{H3}, \mathrm{L1}, \mathrm{L2})$ and sediment samples deposited on Podari river bank (P1 ... P11). Note that: a) P1 is the oldest layer, the one at the bottom of the trench, and $P 11$ is the more recently deposited layer; $b)$ The three fractions $<63 \mu \mathrm{m},<40 \mu \mathrm{m}$ and $<20 \mu \mathrm{m}$ were used for each of the 5 coal samples, which can be identified by the name of the exploitation area from which they were collected

Even though the correlation strength decreases with the granulometric fraction becoming thicker ( $<20$ microns and $<63$ microns), even the weakest have recorded very good values (correlation coefficient " $r$ " did not drop below 0.88 ).

As a geographical distribution, strictly from the point of view of our analysis, the statistical influence on the chromatic similarities decreases for the bumitunous coal from Jieț - Eastern Jiu - Lonea to the Western Jiu - Vulcan mining areas, and for lignite from Lupoaia (NW of the Motru - Rovinari basin) to Fărcășești (the southern part of the mining basin). Due to the fact that a colorimetric determination is not as precise as a geochemical approach could be and because of the lack of more coal samples from the potential source areas, we cannot say with certainty which are the most contributing mining areas in terms of fine sediment delivery.

In a last step, CHAID (Chi-square automatic interaction detection) technique was used to generate the classification and decision-tree-making to determine how samples' colorimetric features best merge to estimate the influence of the source and intermediate storage areas on the fine sediments delivery downstream, on the studied point bar at Podari hydrometric station. Concretely, the sediment samples were allocated in a number of classes, depending on their levels of complexity, from 3 to 7 classes, as it follows: the first class (all the samples coming from Jiu River, all the samples coming from the tributaries' riverbeds, respectively all the coal samples), to the most complex class (Jiu downstream the mountain area, Eastern Jiu and Western Jiu - in the mountain area, tributaries without coal, tributaries with coal, lignite, bituminous coal, Podari riverbank layers).

The prediction and classification algorithm aimed at yielding which categories of sediment and coal samples are most connected and belong to each other from the spectrocolorimetric signal point of view. The results show that coal samples are 
confused with the sediment samples showing different amounts of coal, originated from Jiu River and its tributaries draining Motru - Rovinari lignite basin. By correctly classifying all the coal samples (due to their darker color shades), the model could still not predict the origin of the coal-enriched river sediments, so no direct connection between sources of sediments from mining areas and the river sediments could be found. However, the classifications do not always succeed in distinguishing between clear sediments of the tributaries and coal - enriched sediments (Fig. 8).

\begin{tabular}{|c|c|c|c|c|c|c|c|c|}
\hline \multirow[b]{2}{*}{ from $\backslash$ to } & \multicolumn{3}{|c|}{ NO. OF SAMPLES CLASSIFIED } & \multicolumn{5}{|c|}{ CORRECTNESS COEFFICIENT OF THE CLASSIFICATION } \\
\hline & Tributary & Coal & Jiu & $\%$ corect & & & & \\
\hline Tributary & 46 & 0 & 0 & $100.0 \%$ & & & & \\
\hline Coal & 0 & 14 & 0 & $100.0 \%$ & & & & \\
\hline Jiu & 5 & 0 & 49 & $90.7 \%$ & & & & \\
\hline from I to & Coal & $\begin{array}{l}\text { Motru - } \\
\text { Rovinari }\end{array}$ & Jiu & Tributaries & $\%$ correct & & & \\
\hline Coal & 14 & 0 & 0 & 0 & $100.0 \%$ & & & \\
\hline Motru - Rovinari & 0 & 8 & 4 & 1 & $61.5 \%$ & & & \\
\hline Jiu & 0 & 0 & 54 & 3 & $94.7 \%$ & & & \\
\hline Tributaries & 0 & 2 & 5 & 23 & $76.7 \%$ & & & \\
\hline from I to & $\begin{array}{c}\text { Bituminous } \\
\text { coal }\end{array}$ & Jiu & E \& W Jiu & Lignite & Tributaries & $\%$ correct & & \\
\hline Bituminous coal & 2 & 0 & 0 & 5 & 0 & $28.6 \%$ & & \\
\hline Jiu & 0 & 45 & 0 & 0 & 2 & $95.7 \%$ & & \\
\hline E \& W Jiu & 0 & 6 & 2 & 0 & 1 & $22.2 \%$ & & \\
\hline Lignite & 0 & 0 & 0 & 7 & 0 & $100.0 \%$ & & \\
\hline Tributaries & 0 & 12 & 0 & 0 & 32 & $72.7 \%$ & & \\
\hline from I to & $\begin{array}{c}\text { Bituminous } \\
\text { coal }\end{array}$ & Jiu & E \& W Jiu & Lignite & $\begin{array}{c}\text { Tributaries } \\
\text { with coal }\end{array}$ & $\begin{array}{c}\text { Tributaries } \\
\text { without coal }\end{array}$ & $\%$ correct & \\
\hline Bituminous coal & 2 & 0 & 0 & 5 & 0 & 0 & $28.6 \%$ & \\
\hline Jiu & 0 & 46 & 0 & 0 & 1 & 1 & $95.8 \%$ & \\
\hline E \& W Jiu & 0 & 6 & 3 & 0 & 0 & 0 & $33.3 \%$ & \\
\hline Lignite & 0 & 0 & 0 & 7 & 0 & 0 & $100.0 \%$ & \\
\hline Tributaries with coal & 0 & 6 & 1 & 0 & 14 & 1 & $63.6 \%$ & \\
\hline Tributaries without coal & 0 & 5 & 0 & 0 & 1 & 15 & $71.4 \%$ & \\
\hline from I to & $\begin{array}{c}\text { Bituminous } \\
\text { coal }\end{array}$ & Jiu River & E \& W Jiu & Lignite & $\begin{array}{c}\text { Jiu riverbank } \\
\text { at Podari }\end{array}$ & $\begin{array}{l}\text { Tributaries } \\
\text { with coal }\end{array}$ & $\begin{array}{c}\text { Tributaries } \\
\text { without coal }\end{array}$ & $\%$ correct \\
\hline Bituminous coal & 2 & 0 & 0 & 5 & 0 & 0 & 0 & $28.6 \%$ \\
\hline Jiu River & 0 & 25 & 0 & 0 & 0 & 0 & 0 & $100.0 \%$ \\
\hline E \& W Jiu & 0 & 4 & 3 & 0 & 2 & 0 & 0 & $33.3 \%$ \\
\hline Lignite & 0 & 0 & 0 & 7 & 0 & 0 & 0 & $100.0 \%$ \\
\hline Jiu riverbank at Podari & 0 & 2 & 0 & 0 & 18 & 1 & 2 & $78.3 \%$ \\
\hline Tributaries with coal & 0 & 5 & 1 & 0 & 2 & 13 & 1 & $59.1 \%$ \\
\hline Tributaries without coal & 0 & 1 & 0 & 0 & 2 & 1 & 17 & $81.0 \%$ \\
\hline
\end{tabular}

Fig. 8. The CHAID confusion matrix between sediment and coal samples. "Source of coalenriched sediments" on the vertical and dependant variables on the horizontal

Nonetheless, the algorithm works well only for a small number of classes $(3$, or 4 ), and as the number of classes increases (6 or 7), the model fails to determine the suitability of a sample in one class or another. In some cases, sediments with a certain coal content are classified as coming from coal-free source areas. In Fig. 8, the matrix of confusion shows that sediments on clean tributaries, unaffected by mining, are confused with darker sediments from Jiu or from tributaries containing coal. Yet, in distinguishing between lignite and bituminous coal, the model was 
somewhat successful, with lignite always correctly identified, while bituminous coal sometimes confused with lignite, because of its lighter black shade.

\section{CONCLUSIONS}

The paper investigated, by means of the colorimetric and image analysis, the contribution of the areas with coal mining activities to fine sediment delivery in Jiu River basin, based on 88 samples of fine river sediment and 5 samples of bulk coal. From a methodological point of view, the technique of segmenting coal grains through image analysis needs to be refined and correlated with the true coal content, based on the geochemical analysis.

The colorimetric classifications have highlighted the link between the "coal content" and some of the colorimetric indices $\left(\mathrm{a}^{*}, \mathrm{~b}^{*}, \mathrm{y}, \mathrm{C}^{*}\right.$ and $\left.\mathrm{v}^{\prime}\right)$; however, the strength of the relationship between coal content and spectrocolorimetric signature needs further inquiry, especially in terms of the predictability limit of the coal content based on the colorimetric techniques.

For the coal samples, the fractions $<40$ microns are the most suitable for the correlations, as they show a difference between spectral response between the two types of coal (bituminous and lignite). However, in the classification model, bituminous coal could not be differentiated from lignite in all cases, which raises questions about whether or not all coal samples are representative for the purposes of our study, whereas, lignite proved to be a good predictor.

Samples from the vertical riverbank profile downstream Podari hydrometric station show heterogeneous evidence of fine sediment deposition, which demonstrates the non-linear relationship between their depth and the "coal content" based on spectrocolorimetry and image analysis. Consequently, a thorough hydrological analysis must be carried out to identify coal mining sub-basins that have contributed most to the deposition of sediments.

In the case of Jiu River, the hypothesis of upstream - downstream coherence in the values of colorimetric indices was not proved. Likewise, there was no link between coal content/coal grains surface (\%) and the distribution of colorimetric indices for Jiu River and its tributaries.

Based on the preliminary information obtained on coal color, it will be attempted to improve the calibration of the measurements, taking into account the specific wavelengths that best characterize the color range of the two-coal species.

\section{ACKNOWLEDGEMENTS}

The authors warmly thank Cedric Legout (UGA - IGE) for his help in understanding and implementing the colorimetric analysis techniques and Nathaniel Findling (UGA - ISTerre) for the careful technical support provided in the use of the binocular loupe. We also thank Patricia Ortega Ramirez for initiating Gabriela Moroșanu in the use of image analysis software. 


\section{REFERENCES}

1. Arganda-Carreras I., Kaynig V., Rueden C. (2017), Trainable Weka Segmentation: a machine learning tool for microscopy pixel classification. Bioinformatics, 1;33(15), 2424-2426. DOI:10.1093/bioinformatics/btx180

2. Haddachi A., Ryder D.S., Evrard O., Olley J. (2013), Sediment fingerprinting in fluvial systems: review of tracers, sediment sources and mixing models. International Journal of Sediment Research, 28, 560-578. DOI: 10.1016/S1001-6279(14)60013-5.

3. ISRBC (2015), Towards practical guidance for sustainable sediment management using the Sava River Basin as a showcase. Establishment of the Sediment Monitoring System for the Sava River Basin, 49p.

4. Juez C., Hassan M.A., Franca M.J. (2018), The origin of fine sediment determines the observations of suspended sediment fluxes under unsteady flow conditions. Water Resources Research, 54(8), 5654-5669. DOI: doi:10.1029/2019wr022982.

5. Konica Minolta (2009), Precise Color Communication. Color Control From Perception To Instrumentation, KONICA MINOLTA SENSING, 59 p.

6. Latuf M., Amaral E. (2016), Assessment of suspended sediment discharge in the Purus River basin, Brazil. International Journal of River Basin Management, 14(4), 413 - 429. DOI: 10.1080/15715124.2016.1215322.

7. Legout C., Poulenard J., Nemery J., Navratil O., Grangeon T., Evrard O., Esteves M. (2013), Quantifying suspended sediment sources during runoff events in headwater catchments using spectrocolorimetry. Journal of Soils Sediments, 13(8), 1478-1492. DOI: 10.1007/s11368-013-0728-9.

8. Navratil O., Evrard O., Esteves M., Legout C., Ayrault S., Nemery J., Mate-Marin A., Ahmadi M., Poirel A., Bonte P. (2012), Temporal variability of suspended sediment sources in an alpine catchment combining river/ rainfall monitoring and sediment fingerprinting. Earth Surface Processes and Landforms, 37(8), 828 - 846. DOI: 10.1002/esp.3201

9. Némery J., Mano V., Coynel A., Ercheber H., Moatar F., Meybeck M., Belleudy P., Poirel A. (2013), Carbon and suspended sediment transport in an impounded alpine river (Isère, France), Hydrological Processes, 27(17), 2498 - 2508. DOI: 10.1002/hyp.9387

10. Owens P.N., Batalla R.J., Collins A.J., Gomez B., Hicks D.M., Horowitz A.J., Kondolf G.M., Marden M., Page M.J., Peacock D.H., Petticrew E.L., Salomons W., Trustrum N.A. (2005), Fine-grained sediment in river systems: environmental significance and management issues. River research and aplications, 21(7), 693 - 717, DOI: 10.1002/rra.878

11. Piqué Altés G. (2017), Analysis of hydro-sedimentary processes and impacts affecting river basins and channels, University of Lleida, $166 \mathrm{p}$.

12. Preda I. (1979), Geologia zăcămintelor de cărbuni (Note de curs și lucrări practice), Universitatea din București, Faculty of Geology-Geography, Bucharest, 358 p.

13. Prodanov D., Verstreken K. (2012), Automated Segmentation and Morphometry of Cell and Tissue Structures. Selected Algorithms in Image J. Molecular Imaging, 183-208, DOI: 10.5772/36729.

14. Rădoane M., Rădoane N. (2005), Dams, sediment sources and reservoir silting in Romania. Geomorphology, 71(1-2), 112-125. DOI: 10.1016/j.geomorph.2004.04.010

15. Sang P.N., Liu Z., Zhao Y., Zhao X., Pha P.D., Long H.V. (2018), Chemical weathering in central Vietnam from clay mineralogy and major-element geochemistry of sedimentary rocks and river sediments. Heliyon, 4(7), DOI: 10.1016/j.heliyon.2018.e00710.

16. SedNet (2009), Integration of Sediment in River Basin Management, 44 p. URL: www.sednet.org. Accessed on 02.01.2018.

17. Viscara Rossel R.A., Walwoort D.J.J., McBratney A.B., Janik L.J. (2006), Visible, near infrared, mid infrared or combined diffuse reflectance spectroscopy for simultaneous assessment of various soil properties. Geoderma, 131(1-2), 59 - 75. DOI: 10.1016/j.geoderma.2005.03.007 